THE WABASH CENTER

JOURNAL ON TEACHING
BOOK REVIEW

\section{Teachers, Teaching, and Media}

\author{
Mary M. Dalton and Laura R. Linder, editors \\ Leiden, the Netherlands: Brill Academic Publishers, 2019 \\ (xvi + 213 pages, ISBN 978-90-04-39809-5, \$54.00)
}

Reviewed By

Steven C. Ibbotson

Prairie Colleges
Teachers, Teaching, and Media compiles fifteen essays discussing how educators are presented in popular American television and movies. Each essay interacts with these media forms suggesting ways they reflect or challenge cultural understandings of educators and the school context. In each analysis, the authors demonstrate the editors' thesis that viewers accept various stereotypical representations of teachers without giving critical attention to the ideological underpinnings.

Most of the essays focus on stereotypes regarding gender and race, specifically, on male characters as administrators and female characters as teachers, often in an adversarial role with superiors. In terms of race, teachers function either as agents reinforcing ideas of identity and power or as agents challenging cultural expectations. Jill Ewing Flynn's essay recounting her experiences teaching a post-secondary course on the book's topic provides the broadest overview of the various ideas discussed. In fact, an argument could be made that it should have been the opening essay of the book (rather than the fifth essay), because it provides an overview and introduction to the other examples.

Throughout many essays, the writers note the stereotyping of gender roles in education, the objectification of females, and the racial interactions between students and teachers, as well as among teachers and administrators. Chad E. Harris' commentary about the HBO program Vice Principles and Naeemah Clark's discussion of HBO's Insecure focus specifically on these issues. Network television shows like Saved by the Bell and The Wonder Years are also examined with these themes in mind. Kristy Liles Crawley looks at these stereotypes in movies and television, comparing the depiction of educators in community colleges and universities. Andrew Wirth's interaction with gender assumptions in "Rethinking Student-Teacher Relationship Intimacy as Attachment” was challenging to read, given the reviewers' unfamiliarity with the movie Detachment or queer theory.

Another commonly discussed theme is the "teacher as hero" narrative. The book's first essay by Steve Benton's shows how the educator-hero story actually functions contrary to the original concepts of education held by America's founding fathers. Roslin Smith's essay explains how the character Q from Star Trek: The Next Generation also reflects the teacher as hero narrative. Other essays noted above also touch on this hero theme. Not surprisingly, in the book's final essay, Dalton explores the related concept of the "good teacher" as well as the gender and racial stereotypes discussed earlier.

Other essays interact with other media, examining additional themes. Stephanie Schroder takes an interesting look at the depiction of teachers in the first two seasons of The West Wing, contrasting them with the socio-political milieu of the time. Another essay compares George Miller's teacher-like role in Saving Private Ryan and demonstrates the interesting parallelism of language between two seemingly different contexts: education and the military. Not unlike Steve Benton's opening essay, Gary Kenton's work shows how the anti-authority message of rock n' roll and rap music consistently undermines the value of education and the profession of teachers. Likewise, Elizabeth Currin examines the unique context and storylines in the show Bob's Burgers, considering the various interpretations of the concept in loco parentis.

The inclusion of pictures with many of the essays was helpful in jogging one's memory of the film or television show. Likewise, the essays generally demonstrate good interaction with both the literature published on the media under discussion as well as with other theoretical knowledge. 
Some essays demonstrated book's thesis - film and television both challenge and reflect society's view of education more strongly than others. A good portion of the essays attempted to interact with media that depicted normal everyday life in an American educational setting. However, a few essays seemed focussed on situations beyond the ordinary context of education, and thus were not beneficial in accomplishing the purpose (Star Trek, Saving Private Ryan).

While the book might be interesting for a college class relating to popular culture or media and education, this reviewer suspects the range of examples, the varying quality of analysis, and of course, the ever changing examples in today's popular culture, would render this book to be of minimal value as a textbook. Recognizing that the editors did not write with a particular faith perspective in mind, the book, while interesting, does not seem to this reviewer to be of specific value to faculty involved in teaching religion or theology. 